\title{
Association of body mass index with breakfast in medical student.
}

1. MBBS, DCN, MCPS, M.Phil, Ph.D Scholar

Assistant Professor Physiology Baqai Medical University Karachi.

2. MBBS, MCPS

Assistant Professor Community Medicine

Karachi Medical and Dental College Karachi.

3. MBBS

Postgraduete student / RMO Civil Hospital Karachi.

4. MBBS, FCPS (Hematology) Professor Pathology

Karachi Medical and Dental College Karachi.

5. Final Year Medical Student Karachi Medical and Dental College Karachi.

6. Final Year Medical Student Karachi Medical and Dental College Karach

Correspondence Address:

Dr. Saleemullah Abro

Department of Physiology

Baqai Medical University Karachi.

saleemullahabro41@gmail.com.

Article received on:

16/05/2020

Accepted for publication:

19/09/2020

\section{INTRODUCTION}

The breakfast is considered as an important meal of the human body, as it follows longer duration of the fasting and contributes significantly towards achieving daily nutritional intake in the human body. So it exerts positive effects on lifestyle, behavior, stress, levels of concentration or cognitive performance or memory (short term, spatial and recall), visual or auditory pathway, and energy system of human body. The breakfast intake or consumption is considered as a marker of dietary pattern, which includes micro and macronutrients. The breakfast provides higher concentration of carbohydrates, proteins, dietary fibers, iron, calcium and vitamin $\mathrm{C}$ and lower concentration of fats. ${ }^{1,2}$ The breakfast consumption and pattern of food taken is associated with decreased body mass index $\left(\mathrm{BMl} ; \mathrm{kg} / \mathrm{m}^{2}\right)$, weight loss or maintenance of nutritional status of the human body and exerts positive effects on cardiovascular system by two distinct pathway (breakfast composition and skipping).3,4,5 The breakfast consumption containing high concentration of protein and whole grain or fibers, is directly associated with positive effects on cardiovascular system, metabolic syndrome and overweight or obesity. ${ }^{6,7}$ The breakfast containing the high concentration of cereal based meals will provide vitamins and an essential minerals and exerts effects as a lipid lowering agent. ${ }^{8}$ It depends on the education level or literacy of parents or family members too. ${ }^{3}$ The students' behavior and attitude towards unhealthy dietary habits or consumption of high energy dense nutrients (junk foods or high caloric snacks or fast foods or use of beverages), decrease intake of fresh fruits or fresh juices and habit of skipping breakfast. ${ }^{9}$ The habit of breakfast skipping is associated with lower quality of dietary nutrients and increased intake of 
concentrated foods. It is an associated with noncommunicable diseases (NCD's) like increased body mass index (BMl; $\left.\mathrm{kg} / \mathrm{m}^{2}\right)$ or overweight or obesity, metabolic disorders, osteoporosis, ischemic heart disease (IHD) or congestive cardiac failure (CCF), hypertension (HTN), stroke, diabetes mellitus (type 2), mood disturbances or excessive irritability, menstrual problems, easy fatigability, impaired memory and development of stress or anxiety. ${ }^{10}$ Non communicable diseases (NCD's) are considered as among top ten causes of morbidity and mortality in Pakistan. ${ }^{11}$ Many factors are associated with skipping of breakfast like, age, gender, socioeconomic status, physical health, body mass index (BMI), sleeping quality and dietary habits in students. ${ }^{1}$ Multiple studies have evaluated that the skipping of breakfast is positively correlated with the development of overweight or obesity and metabolic syndrome. ${ }^{1,12}$ The breakfast composition in university students had poor intake of fruits, vegetables, milk, dairy products and intake of high concentration of sweets, junk foods, bakery products, chocolates, and tin packed foods ${ }^{13,14,15}$ Nowadays overweight or obesity is increasing among the medical college students and it is due to erratic eating habits or excessive use of junk foods. These dietary habits are responsible for increasing risk factors of developing non communicable diseases (NCD's), so research related to these risk factors (Erratic eating habits or excessive use of junk foods) is an essential, considering the role of medical college students as future consultants or physicians or surgeons and acts as role models in society. The present study was conducted as to find out the association of body mass index $\left(\mathrm{BMl} ; \mathrm{kg} / \mathrm{m}^{2}\right)$ with the breakfast in medical student of Karachi.

\section{MATERIAL \& METHODS}

Ethical review board (ERB) of Karachi medical and dental college (KMDC) had given an ethical approval of research and this descriptive crosssectional study was done. In this study medical and dental students were enrolled from the public medical institutes of Karachi. This study was conducted in Dow University of health sciences (DUHS), Jinnah Sindh medical university (JSMU), and Karachi medical and dental college (KMDC) of Karachi. A total 382 medical and dental students were enrolled or taken after calculation of sample size by Raosoft with alpha level 5\% and 95\% confidence level in this study and having 18-24 years of age. The participants of this study were briefed and explained about its importance of research. This study was extending over duration of two months, from $1^{\text {st }}$ January to $31^{\text {st }}$ March 2019. Sampling technique of this descriptive study was Non probability; convenience sampling. All included students of medical and dental were taken from class first year to fourth year of public medical institutes of Karachi with written consent. The students having history of anorexia, nausea, vomiting, lactase deficiency, gluten sensitivity, hormonal disorders or uncontrolled sugar, anorexia nervosa and fasting of Ramadan were excluded from the study. Demographic data (age, gender, and body weight $(\mathrm{Kg})$ and height $\left(\mathrm{m}^{2}\right)$ and breakfast habits were collected and gathered from the participants of public medical institutes with the pre-tested questionnaire. The permission before entering in the medical institutes was granted before the start of data collection. Short announcement was done before the start of first class as to inform the salient features of this study; pre-tested questionnaire was distributed to students and collected back after second lectures. The weight $(\mathrm{Kg})$ and height $\left(\mathrm{m}^{2}\right)$ of all included medical and dental students were measured. The Body mass index (BMI; $\mathrm{kg} / \mathrm{m}^{2}$ ) was calculated by using self-reported weight and height. Body mass index (BMl; $\mathrm{kg} / \mathrm{m}^{2}$ ) was categorized on bases of international classification into four groups; 1) underweight (BMI $\leq 18.5)$, 2) normal weight (BMI < 25), 3) overweight (BMI between 25 and 30) and 4) obese (BMI $\geq 30) \cdot{ }^{16}$ All demographic data was double checked, verified for missing or incomplete entries and then entered and analyzed through Statistical Package for Social Sciences (SPSS) version 22. Frequency, percentage (\%) and mean \pm standard deviation for assessment of numerical variables. Statistical comparisons of mean scores were performed using independent sample t-test. For qualitative variables, Chi-square test $\left(\mathrm{X}^{2}\right)$ was applied. Tables were generated by using Microsoft word and Excel sheets in this study. The Pearson Chi Square test was used for evaluating the association of breakfast practices with studied variables ((BMl; kg/m2, gender) of 
studied samples. The $p<0.05$ was considered as a statistical significant difference and $p>0.05$ was considered as statistical non-significant differences in this study.

\section{RESULTS}

Table -I report the baseline characteristics of studied samples, in this present study there were 382 medical students. KMDC, DUHS and JSMU students were included $45.3 \%, 30.9 \%$ and $23.8 \%$ respectively. Females were $84.8 \%$ and males were $15.2 \%$ in this study, $29.8 \%$ were from $4^{\text {th }}$ year students and majority of participants were found underweight $(79.6 \%)$ with only $3.7 \%$ were overweight or obese students. Gender based comparison of demographic parameters of the participants like mean age of participants was $20.83 \pm 1.54$ years, mean age of male \& females were $20.71 \pm 1.545: 20.85 \pm 1.543$ respectively showed statistically non-significant $(p>0.05)$ differences, mean weight was $55.78 \pm 10.81 \mathrm{~kg}$, mean weight of male \& females were 69.48 $\pm 12.365: 53.32 \pm 8.444$ respectively showed statistically significant $(p<0.05)$ differences, mean height was $1.90 \pm 0.11$ meters, mean height of male \& females were 1.9107士.10047: $1.9027 \pm .11664$ respectively showed statistically non-significant $(p>0.05)$ differences, mean Body mass index (BMI) was $15.53 \pm 3.5 \mathrm{~kg} /$ $\mathrm{m} 2$, mean body mass index of male \& females were $19.2215 \pm 4.20181: \quad 14.8783 \pm 2.92753$ respectively showed statistically significant $(p<0.05)$ differences (Table-II). The participants did breakfast $81.4 \%$ and omit or skip breakfast was $18.6 \%$. The breakfast skippers, females and males were $85.9 \%$ : $14.1 \%$ respectively (Table-III). Table-IV showed the association of breakfast (yes done and omit or skip breakfast) with studied variables. Only body mass index (underweight, normal weight, and overweight/obese) had as statistically significant $(p<0.05)$ association with practices of breakfast, while gender based comparison and various institute (DUHS, JSMU \& KMDC) comparison did not showed significant $(p>0.05)$ association with breakfast in medical students.

\begin{tabular}{|l|l|c|c|}
\hline \multicolumn{2}{|c|}{ Characteristics } & N & $\%$ \\
\hline \multirow{3}{*}{$\begin{array}{l}\text { Name of } \\
\text { Institute }\end{array}$} & DUHS & 118 & 30.9 \\
\cline { 2 - 4 } & JSMU & 91 & 23.8 \\
\cline { 2 - 4 } & KM\&DC & 173 & 45.3 \\
\hline \multirow{3}{*}{ Gender } & Male & 58 & 15.2 \\
\cline { 2 - 4 } & Female & 324 & 84.8 \\
\hline \multirow{4}{*}{$\begin{array}{l}\text { Year of } \\
\text { Study }\end{array}$} & $1^{\text {st }}$ year & 96 & 25.1 \\
\cline { 2 - 4 } & $2^{\text {nd }}$ year & 73 & 19.1 \\
\cline { 2 - 4 } & $3^{\text {rd }}$ year & 99 & 25.9 \\
\cline { 2 - 4 } & $4^{\text {th }}$ year & 114 & 29.8 \\
\hline \multirow{4}{*}{ BMI } & Underweight & 304 & 79.6 \\
\cline { 2 - 4 } & Normal & 64 & 16.8 \\
\cline { 2 - 4 } & Overweight/obese & 14 & 3.7 \\
\hline
\end{tabular}

Table-I. Baseline characteristics of studied samples $(n=382)$.

\begin{tabular}{|c|c|c|c|c|}
\hline & Gender & $\begin{array}{l}\text { Mean } \pm \text { S. } \\
\text { Deviation }\end{array}$ & $\begin{array}{l}\text { Mean } \pm \text { S. } \\
\text { Deviation }\end{array}$ & P-Value \\
\hline \multirow{2}{*}{$\begin{array}{l}\text { Age } \\
\text { (years) }\end{array}$} & Male & \multirow{2}{*}{$\begin{array}{c}20.83 \pm \\
1.54\end{array}$} & $\begin{array}{c}20.71 \pm \\
1.545\end{array}$ & \multirow{2}{*}{0.52} \\
\hline & Female & & $\begin{array}{c}20.85 \pm \\
1.543\end{array}$ & \\
\hline \multirow{2}{*}{$\begin{array}{l}\text { Weight } \\
(\mathrm{kg})\end{array}$} & Male & \multirow{2}{*}{$\begin{array}{c}55.78 \pm \\
10.81\end{array}$} & $\begin{array}{c}69.48 \pm \\
12.365\end{array}$ & \multirow{2}{*}{$0.000^{*}$} \\
\hline & Female & & $\begin{array}{c}53.32 \pm \\
8.444\end{array}$ & \\
\hline \multirow{2}{*}{$\begin{array}{l}\text { Height } \\
\text { (m) }\end{array}$} & Male & \multirow{2}{*}{$\begin{array}{c}1.90 \pm \\
0.11\end{array}$} & $\begin{array}{c}1.9107 \pm \\
.10047\end{array}$ & \multirow{2}{*}{0.625} \\
\hline & Female & & $\begin{array}{c}1.9027 \pm \\
.11664\end{array}$ & \\
\hline \multirow{2}{*}{$\begin{array}{l}\mathrm{BMI} \\
(\mathrm{kg} / \mathrm{m} 2)\end{array}$} & Male & \multirow{2}{*}{$\begin{array}{l}15.53 \\
\pm 3.5\end{array}$} & $\begin{array}{c}19.2215 \pm \\
4.20181\end{array}$ & \multirow{2}{*}{$0.000^{*}$} \\
\hline & Female & & $\begin{array}{l}14.8783 \\
2.92753\end{array}$ & \\
\hline
\end{tabular}

Table-II. Gender based comparison of demographic parameters of the participants $(n=382)$

Statistical comparisons of mean scores were performed using independent sample t-test, ${ }^{\star} \mathrm{p}<0.05$ was considered significant.

\begin{tabular}{|c|c|c|c|c|c|}
\hline \multicolumn{2}{|c|}{ Questions } & \multirow{2}{*}{\multicolumn{3}{|c|}{$\begin{array}{c}\mathbf{N} \\
311\end{array}$}} & Percentage \% \\
\hline \multirow{3}{*}{$\begin{array}{l}\text { Do you have breakfast in the } \\
\text { morning? }\end{array}$} & Yes & & & & 81.4 \\
\hline & \multirow{2}{*}{ No/Skip/omit } & 71 & Male & $10(14.1 \%)$ & \multirow{2}{*}{18.6} \\
\hline & & $\pi$ & Female & $61(85.9 \%)$ & \\
\hline
\end{tabular}




\begin{tabular}{|c|c|c|c|c|c|c|}
\hline \multirow{3}{*}{\multicolumn{2}{|c|}{ Characteristics }} & \multicolumn{4}{|c|}{ Do you have breakfast in the morning? } & \multirow{3}{*}{ P-Value } \\
\hline & & \multicolumn{2}{|c|}{ Yes } & \multicolumn{2}{|c|}{ No } & \\
\hline & & $\mathbf{N}$ & $\%$ & $\mathbf{N}$ & $\%$ & \\
\hline \multirow{3}{*}{ Name of Institute } & DUHS & 98 & 31.5 & 20 & 28.2 & \multirow{3}{*}{0.84} \\
\hline & JSMU & 74 & 23.8 & 17 & 23.9 & \\
\hline & KM\&DC & 139 & 44.7 & 34 & 47.9 & \\
\hline \multirow{2}{*}{ Gender } & Male & 48 & 15.4 & 10 & 14.1 & \multirow{2}{*}{0.77} \\
\hline & Female & 263 & 84.6 & 61 & 85.9 & \\
\hline \multirow{3}{*}{ BMI } & Underweight & 255 & 82.0 & 49 & 69.0 & \multirow{3}{*}{$0.036^{*}$} \\
\hline & Normal & 47 & 15.1 & 17 & 23.9 & \\
\hline & Overweight/obese & 9 & 2.9 & 5 & 7.0 & \\
\hline & $\begin{array}{r}\text { Table-I } \\
* p<0.05 \text { was }\end{array}$ & of of & $\begin{array}{l}\text { with s } \\
\text { ng Pe }\end{array}$ & $\begin{array}{l}\text { iabl } \\
\text { Squ }\end{array}$ & & \\
\hline
\end{tabular}

\section{DISCUSSION}

The present study aimed to find out the association of body mass index $\left(\mathrm{BMl} ; \mathrm{kg} / \mathrm{m}^{2}\right)$ with the breakfast in medical students of Karachi. The mean age of participants was $20.83 \pm 1.54$ years in our study results, similar to study reported in Malaysian study. ${ }^{17}$

The total number of study participants was 382 and majorities were females 324 (84.8\%). It is like other studies in which mostly participants were females and sample was range from 300 to $600 .{ }^{18,19}$ According to our study results, the majority of medical students were found in underweight or Thinness category (79.6\%) and only $3.7 \%$ were overweight/ obese in different medical institutes of Karachi. Similar to our findings of higher frequency of thinness was observed by Cusick and Kuch in their study. ${ }^{20}$ The gender based comparison of weight $(\mathrm{Kg})$ and body mass index (BMl; $\mathrm{kg} / \mathrm{m}^{2}$ ) showed statistically significant $(p<0.05)$ differences in our study, like our results. Similar study was done in Kuwait University by Dalal Alkazemi. ${ }^{21}$ This supports our results. Under weight or thinness was expressed as low body mass index (BMI $\leq 18.5)$ for age in individual. The weight is considered as an indicator of age not for height and it was more prevalent in the Southeast Asian region. ${ }^{22}$ Many factors affect the weight but genetic factors mainly determine the height and it exerts adverse effects on human body like disturbed menstrual cycle, disturbed cognition, emotional disturbances or stress, increased absentees from class or poor performance in academics and delayed maturation and decreased muscle strength or decreased bone mineral density, so these disturbances affects the adolescents health by physically and mentally. ${ }^{20,22}$ Underweight or thinness and overweight or obesity are considered as a double burden. These can be due to heterogeneity of malnutrition in adolescents. ${ }^{22}$ According to our study results, the participants did breakfast $81.4 \%$ and omit or skip breakfast was $18.6 \%$. Among breakfast skippers, females were $85.9 \%$ and males were $14.1 \%$ respectively. Similar to our findings, prevalence of doing breakfast observed in western countries like United States of America, in France and in Australia ( $80 \%, 90 \%$, and $72.5 \%$ respectively) and breakfast skipper similar to our results in India, America, in France, and in Australia (14.8\%, 20\%, $10 \%$, and $27.5 \%$ respectively. ${ }^{23,24}$ In our study results, mostly females were skipping breakfast as compared to males. Like our results, study was done in Alexandria University, Egypt. ${ }^{25}$ It is due to over thinking about being overweight as compared to normal or ideal weight. Hence mostly girls adopt the habit of skipping breakfast. According to our study results body mass index (underweight, normal weight, and overweight/ obese) had as statistically significant $(p<0.05)$ association with breakfast (done and skipped or omit), while gender based comparison did not showed significant $(p>0.05)$ association with breakfast practices in medical students. Similar to our results, an Egyptian study supported our findings ${ }^{25}$ The habit of breakfast skipping was one of the leading factor for development of overweight 
or obesity in adolescents. It results with decrease intake of fiber diet iron, and calcium, increased concentration of insulin level after meal or higher insulin resistance level or metabolic syndrome (MetS), lack of satiety and disturbed circadian rhythm of glucose homeostasis, increased breakdown of fat with low grade of inflammation and consumption of junk foods or fast foods. ${ }^{25}$ These factors are considered as leading factors for development of non communicable diseases (NCD's) or chronic disorders in future.

\section{CONCLUSION}

According to our study findings, this can be concluded that the majority of participants were females, and habit of skipping breakfast most common in them, so body mass index were $<18.5$ $\mathrm{kg} / \mathrm{m} 2$ in them and the Body mass index had as statistically significant $(p<0.05)$ association with breakfast.

Copyright@ 19 Sep, 2020.

\section{REFERENCES}

1. Goon et al., Factors associated with breakfast skipping among urban adults in Bangladesh. Glob. Res. J. Publ. Health. Epidemiol. 2014; 2(6):037-042.

2. Raeesa Seedat \& Kirthee Pillay. Breakfast consumption and its relationship to sociodemographic and lifestyle factors of undergraduate students. South African Journal of Clinical Nutrition 2019: 1-7.

3. Deshmukh-- - Taskar PR, Nicklas TA, O'Neil CE, Keast DR, Radcliffe JD, ChoS. The relationship of breakfast skipping and type of breakfast consumption with nutrient Intake and weight status in Children and adolescents: The National Health and Nutrition Examination Survey 1999-- $\square$ 2006. J Am Diet Assoc 2010; 110(6):869--- 8878.

4. Dwairji MAA, Husain WA, Al-Qaoud NM, et al. Breakfast consumption habits and prevalence of overweight and obesity among Kuwaiti adolescents. J Nutr Health Food Eng. 2018; 8(2):94-103.

5. Quatela A, et al. The Energy Content and Composition of Meals Consumed after an Overnight Fast and Their Effects on Diet Induced Thermogenesis: A Systematic Review, Meta-Analyses and MetaRegressions. Nutrients. 2016; 8(11).
6. Leidy $\mathrm{HJ}$, et al. Evaluating the intervention-based evidence surrounding the causal role of breakfast on markers of weight management, with specific focus on breakfast composition and size. Adv Nutr. 2016; 7(3):56-75.

7. Kim J, Park E, Lee SG, Cho W, Choi Y, et al. Associations between Breakfast Skipping and Body Mass Index, and Type 2 Diabetes in South Korea. Intern Med. 2014; S6: S6-005. doi:10.4172/2165-8048.S6-005.

8. Liyanage et al., Breakfast Habits and It's Relationship to Body Mass Index, Cognitive Function among Final Year Medical Students. J Gen Pract (Los Angel).2017; 5: 311. doi:10.4172/2329-9126.1000311.

9. Dalal Alkazem. Gender differences in weight status, dietary habits, and health attitudes among college students in Kuwait: A cross-sectional study. Nutrition and Health 2019; 25(2): 75-84.

10. Flavia Fayet-Moore, Jean Kim, Nilani Sritharan, and Peter Petocz. Impact of breakfast skipping and breakfast choice on the nutrient intake and body mass index of Australian children. 2016; 8(8): 487.

11. Rafique I, Saqib MAN, Munir MA, Qureshi H, Rizwanullah, Khan SA, et al. Prevalence of risk factors for noncommunicable diseases in adults: Key findings from the Pakistan STEPS survey. East Mediterr Health J. 2018; 24(1):33-41.

12. Sedibe MH, Feeley AB, Voorend C, Griffith PL, Doak CM, Norris SA. Narratives of urban female adolescents in South Africa: Dietary and physical activity practices in an obesogenic environment. S Afr J Clin Nutr. 2014; 27(3):114-119.

13. Van den Berg VL, Abera BMM, Nel M, et al. Nutritional status of undergraduate healthcare students at the University of the Free State. S Afr Fam Pract. 2013; 55(5):445-452.

14. Gresse A, Steenkamp L, Pietersen J. Eating, drinking and physical activity in Faculty of health Science students compared to other students at a South African university. S Afr J Clin Nutr. 2015; 28(4):154159.

15. Kazi HA, Coopoo Y. Physical activity, alcohol use, smoking and dietary profiles of a cohort of university students. Afr J Phys Health Educ Recr Dance. 2010; 104-118.

16. World Health Organization. WHO: Global Database on Body Mass Index n.d. Available from: http://apps. who.int/ bmi/index .jsp ?intro Page=intro_3.html. 
17. Nizar Abdul Majeed Kutty, Tin Yen Ru, Vincent Hwang Qi Chiang, Wee Ying Zhi. Association of dietary habits and body mass index among university students in Malaysia: A cross-sectional study. IOSR Journal of Nursing and Health Science. 2015; Volume 4, Issue 5 Ver. I: PP 78-85.

18. Amruth M, Kumar A. A cross-sectional study on BMI and eating habits among students in a medical college in Kerala. Int $\mathrm{J}$ Community Med Public Health 2019; 6:1285-94.

19. Mahmoud $\mathrm{MH}$, Taha AS. The association between eating habits and body mass index among nursing students. IOSR Journal of Nursing a nd Health Science (IOSR-JNHS). 2017; 6(3):14-26.

20. Cusick and Kuch. Determinants of under nutrition and over nutrition among adolescents in developing countries. adolesc med state art rev. 2012 December ; 23(3): 440-456.
21. Dalal Alkazemi. Gender differences in weight status, dietary habits, and health attitudes among college students in Kuwait: A cross-sectional study. Nutrition and Health 2019, Vol. 25(2) 75-84.

22. Caleyachetty et al. The double burden of malnutrition among adolescents: analysis of data from the global school-based student health and health behavior in school-aged children surveys in 57 low- and middleincome countries. Am j clinnutr. 2018; 108:414-424.

23. Sun et al.: Factors associated with skipping breakfast among Inner Mongolia Medical students in China. BMC Public Health.2013; 13:42.

24. Dr. Prannoy Paul, Dr. Arun N Bhatt, "The prevalence of breakfast skipping among medical students and its neuro-glycopenic effects", ijmsir 2020; 5(1):149-156.

25. Samah Mahmoud Sofar1, Naglaa Abd Allah Abd El Hafeez. Relations between Skipping Breakfast, academic performance and body mass index among undergraduate university nursing students. IOSR Journal of Nursing and Health Science.2019; Volume 8, Issue 4 Ser. V: PP 32-42.

\begin{tabular}{|c|c|c|c|}
\hline \multicolumn{4}{|c|}{ AUTHORSHIP AND CONTRIBUTION DECLARATION } \\
\hline Sr. \# & Author(s) Full Name & Contribution to the paper & Author(s) Signature \\
\hline 1 & Saleemullah Abro & Preception writing up, Proof & \\
\hline 2 & Qurratulain Saleem & Data analysis \& Proof reading. & dxiseleer \\
\hline 3 & Ahad Ahmar Noor & Critical review, Proof readiang. & \\
\hline 4 & Ghulnaz Khalid & Concept \& Drafting study. & \\
\hline 5 & Maham Khan & Data collection & am \\
\hline 6 & Fatima & Data collection & \\
\hline
\end{tabular}

